\title{
CAI - Narzędzia informatyczne wspierające tłumaczy konsekutywnych. Stan badań oraz perspektywy rozwoju
}

\author{
Krzysztof Sitkowski \\ Państwowa Wyższa Szkoła Informatyki i Przedsiębiorczości w Łomży \\ ksitkowski@pwsip.edu.pl
}

\section{Streszczenie}

Celem artykulu jest przedstawienie CAI, czyli narzędzi informatycznych wspierajacych ttumacza $w$ trakcie wykonywania ttumaczeń konsekutywnych. $W$ pierwszej części przedstawiona jest definicja CAI oraz opis i przykłady pierwszej, drugiej i trzeciej generacji tego narzędzia. Na podstawie analizy przedmiotu stwierdzono, że istniejace rozwiazania, $w$ postaci komercyjnej lub testowej, ograniczaja swoje działanie głównie do zarzadzania terminologia. Następnie autor odnosi się do możliwości wykorzystania pamięci tlumaczeniowych $w$ tlumaczeniu konsekutywnym. Kolejna część opisuje dwa najważniejsze komponenty CAI, czyli oprogramowanie do rozpoznawania mowy (ASR) oraz narzędzie kompresujące. $W$ dalszej części przedstawiono możliwe problemy rozwojowe narzędzia oraz opisano kompresję $w$ tłumaczeniu konsekutywnym. W ostatniej części artykułu autor opisuje kompleksowe narzędzie CAI, jego komponenty, a także scenariusz zastosowania $w$ trakcie ttumaczenia konsekutywnego.

Stowa kluczowe: Narzędzie CAI, oprogramowanie do rozpoznawania mowy (ASR), tłumaczenie konsekutywne, kompresja tłumaczeniowa, narzędzie kompresujace

\section{Abstract}

CAI Tools for Consecutive Interpreters. Present Solutions and Development Perspectives

The aim of the article is to present CAI tools, i.e. Computer-Assisted Interpreting tools supporting the interpreter during consecutive interpreting. The first part presents the definition of CAI, a description and examples of the first, second and third generation of this tool. Based on the analysis of the subject, it was found that the existing solutions, either in commercial or test form, are limited to terminology management. Then the author refers to the possibility of using translation memories in consecutive interpreting. The following part describes the two most important components of CAI, namely speech recognition software (ASR) and a compression tool. In the next part, possible development issues are presented. 
Keywords: CAI tools, automatic speech recognition (ASR), consecutive interpreting, compression, compression tools

\section{Wstęp}

Celem niniejszych rozważań jest przedstawienie narzędzi, istniejących w postaci komercyjnej bądź testowej, wykorzystywanych do wspomagania tłumacza w trakcie wykonywania tłumaczeń konsekutywnych. Istnieje grupa rozwiązań (programy komputerowe i aplikacje na urządzenia mobilne), z których większość skupia się na prezentacji terminologii i jej ekwiwalentów opracowanych w fazie przygotowawczej. Badania prowadzone przez m.in. Fannuliego (2016, 2018), Prandi (2017), Rutten (2017) doprowadziły do stworzenia Interpret Termbank, który stanowi jeden z niewielu przykładów takich rozwiązań.

Działanie tych narzędzi ograniczone jest do obsługi terminologii. W związku z tym należy postawić serię pytań: Co z pozostałymi częściami komunikatu? Dlaczego nie wykorzystać możliwości oprogramowania rozpoznającego mowę do przedstawienia jak najpełniejszego konspektu wypowiedzi mówcy? Czy możliwe jest wsparcie tłumacza konsekutywnego inaczej niż tylko za pomogą oprogramowania zarządzającego terminologią? Oczywiście, nie chodzi tutaj o przedstawienie pełnego tekstu wypowiedzi, ponieważ zmieniłoby to charakter tłumaczenia $\mathrm{i}$ wprowadziło dodatkowe utrudnienia związane $\mathrm{z}$ większym przeładowaniem kognitywnym.

Postępujący rozwój technologii informatycznej przez dłuższy czas zdawał się pomijać tłumaczenia ustne. Oczywiście widoczny jest rozwój technologii służącej do przesyłania dźwięku i obrazu pomiędzy uczestnikami tłumaczenia, zapewnienia im wygody oraz przynajmniej minimum możliwości komunikacji. Jednakże, o ile w przypadku tłumaczeń pisemnych powstają oraz są ciągle ulepszane programy typu CAT, a wiedza o nich jest ciągle pogłębiana i popularyzowana za pomocą publikacji naukowych, występów na konferencjach oraz akcji szkoleniowych przygotowywanych lub przynajmniej sponsorowanych przez producentów takiego oprogramowania, to w przypadku CAI sytuacja ta nie wygląda tak optymistycznie. Dlatego też, warto przyjrzeć się istniejącej technologii, która ma wspierać tłumacza ustnego $\mathrm{w}$ trakcie thumaczenia w zakresie wykraczającym poza sprzęt umożliwiający przesyłanie dźwięku. Poszukiwane jest narzędzie, które swoją użytecznością zbliżone będzie do oprogramowania CAT.

Według Gile’a (2009: 157-190), tłumacze ustni pracują na granicy przeciążenia przez większość czasu, co może skutkować błędami i pominięciami. Tłumaczenie ustne jest czynnością wymagającą wielozadaniowości oraz sporego wysiłku umysłowego, który, nawet 
w przypadku wysoce wyspecjalizowanych tłumaczy zawodowych z nienagannym warsztatem, jest przez większość czasu bliski poziomowi maksymalnemu i którego przekroczenie ma zazwyczaj negatywne konsekwencje. Seleskovitch (1975) twierdzi, iż tłumaczenie konsekutywne obejmuje szereg czynności wykonywanych w trzech etapach: rozumienie, dewerbalizację i ekspresję tekstu docelowego. Na ostatnim etapie uruchamiane są mechanizmy interpretacji i pamięci, wspierane przez wykonane wcześniej notatki. Gile (2009: 175-179) ujmuje w swoim modelu wysiłkowym złożoność zadań podejmowanych w trakcie tłumaczenia konsekutywnego i grupuje je w dwóch fazach. W pierwszej z nich dochodzi do słuchania, analizy, notowania, operacji na pamięci krótkotrwałej oraz koordynacji tychże. W tej fazie tłumacz dokonuje konwersji sygnałów dźwiękowych przemówienia do graficznej postaci notatek. Poświęcenie zbyt dużej ilości uwagi tej czynności może zaburzyć słuchanie, analizę i zapamiętywanie co najprawdopodobniej doprowadzi do tego, że tłumacz nie będzie wiedział co ma zanotować. $Z$ kolei w fazie drugiej thumacz odtwarza z pamięci elementy tekstu, śledzi notatki oraz formułuje wypowiedź. Jeżeli notowaniu poświęcona zostanie zbyt mała ilość uwagi, wykonane notatki będą nieczytelne, niekompletne lub/i nieprawidłowo obrazujące strukturę wypowiedzi. Obie fazy wiążą się z wielozadaniowością co stanowi jedno z największych wyzwań tłumaczenia konsekutywnego. Jeżeli thumacz poświęci zbyt wiele uwagi jednej z czynności, pozostałe, najprawdopodobniej, zostaną wykonane nieprawidłowo, co doprowadzi do błędów w obu z nich. Stworzenie odpowiednich narzędzi CAI oraz ich zastosowanie $\mathrm{w}$ trakcie thumaczenia zmniejszy poziom obciążenia kognitywnego thumacza poprzez redukcję ilości wykonywanych zadań (notowanie) i tym samym pozwoli na poświęcenie więcej uwagi pozostałym. To z kolei, może w korzystny sposób przełożyć się na precyzję i jakość tłumaczenia oraz wydolność tłumacza.

\section{Narzędzia CAI}

Narzędzia CAI nie cieszyły się dotąd nadmierną popularnością wśród badaczy. W literaturze fachowej odnaleźć można jedynie bardzo ogólne opisy omawianego zagadnienia. Dlatego też, przyjąć należy, że narzędzia CAI to Computer-Assisted Interpreting lub Computer-Aided Interpreting, czyli narzędzia do tłumaczeń ustnych wspieranych komputerowo, a dokładniej narzędzia informatyczne wspierające tłumacza w trakcie tłumaczeń ustnych, stosowane zarówno w fazie przygotowawczej, jak i w trakcie realnego tłumaczenia, których celem jest podniesienie poprawności i precyzji oraz zmniejszenie poziomu przeładowania kognitywnego oraz zmęczenia tłumacza. 
W literaturze przedmiotu, np. Routledge Encyclopedia of Interpreting Studies (2015) znaleźć można podział technologii stosowanej w tłumaczeniach ustnych na trzy obszary, tj.:

a) technologię wykorzystywaną do wykonywania tłumaczeń ustnych, czyli narzędzia do telekonferencji lub video konferencji, kabiny thumaczeniowe i inne rozwiązania pozwalające na przesyłanie dźwięku i obrazu pomiędzy uczestnikami sytuacji tłumaczeniowej;

b) technologię wykorzystywaną $\mathrm{w}$ procesie szkolenia tłumaczy, czyli np. banki przemówień i wypowiedzi, w których poza nagraniami audio, bądź wideo, znaleźć można transkrypcje, listy terminologii czy informacje o mówcach. Poza tym aplikacje wspierające uczenie się terminologii czy zwiększające możliwości zapamiętywania;

c) technologię wykorzystywaną do wspierania tłumaczy ustnych w procesie tłumaczenia w celu podniesienia poziomu ich produktywności, poprawności i precyzji. Encyklopedia poświęca temu zagadnieniu najmniej uwagi. To właśnie ta kwestia stanowi obszar zainteresowania autora niniejszego artykułu.

Tematyka CAI została też opisana przez m.in. Fantinuoliego (2017, 2018), Compas Pastor (2017), Prandi (2017), Rutten (2017) i innych.

Technologia CAI, według C. Fantinuoliego (2018: 155-157) ukierunkowana jest na proces tłumaczenia (process-oriented) i środowisko thumaczeniowe (setting oriented). CAI ukierunkowane na proces tłumaczenia dotyczy systemów zarządzania terminologią (Terminology Management Systems), narzędzi analizy korpusowej oraz oprogramowania do ekstrakcji wiedzy (knowledge extraction software). Zadaniem wyżej wymienionych jest wspomaganie tłumacza ustnego $\mathrm{w}$ fazie przygotowawczej oraz wykonawczej procesu tłumaczenia. Innymi słowy, CAI ukierunkowane na proces tłumaczenia określić można jako całokształt narzędzi informatycznych wykorzystywanych przez thumacza ustnego w trakcie przygotowań oraz w trakcie sesji thumaczeniowej. Celem zastosowania tych narzędzi jest podniesienie jakości tłumaczenia oraz zwiększenie możliwości tłumaczeniowych poprzez odciążenie tłumacza. Takimi narzędziami mogą być słowniki terminologiczne, systemy notujące i kompresujące postać zebranych informacji, konwertery jednostek miary, wyświetlacze schematów technicznych i ilustracji oraz aplikacje wspomagające zapamiętywanie.

Do CAI ukierunkowanych na środowisko tłumaczeniowe zaliczyć można wszelkie urządzenia towarzyszące, ale nie wspierające tłumacza w samym procesie tłumaczenia, tj. kabiny tłumaczeniowe, mikrofony, słuchawki, konsole, przekaźniki dźwięku itd. Można 
stwierdzić, że narzędzia te ograniczają swoją funkcję głównie do umożliwienia komunikacji jedno- lub wielostronnej pomiędzy uczestnikami sytuacji tłumaczeniowej. O ile narzędzia takie pełnią bardzo ważną rolę w procesie tłumaczenia, to nie ingerują w sam proces.

Narzędzia CAI podzielić można na kilka grup. Do najpopularniejszych należą narzędzia terminologiczne służące do tworzenia list terminologii, ich automatycznego tłumaczenia, wyszukiwania i wspomagania zapamiętywania. Niektóre $\mathrm{z}$ nich mają możliwość automatycznej ekstrakcji terminów (EU Bridge Interpreter Wizard) oraz importu list terminów utworzonych w MS Word lub MS Excel. Dwa przykłady tego typu narzędzi są dokładniej opisane w dalszej części niniejszego artykułu.

Następnie, wyróżnić należy narzędzia rozpoznawania mowy, których zadaniem jest konwersja dźwięku do tekstu. Niestety, oprogramowanie tego typu nie jest jeszcze wolne od wad. Do źródeł najpoważniejszych problemów zaliczyć należy niewyraźną mowę, błędy w wymowie, mało popularne akcenty, zakłócenia wynikające z odgłosów otoczenia.

Kolejną grupę stanowią narzędzia notujące - aplikacje takie jak Inkeness, LectureNotes, za pomocą których można robić notatki i przesyłać je drogą elektroniczną. Istnieją także rozwiązania pozwalające na nagrywanie wypowiedzi oraz łączenie zapisanych nagrań z notatkami sporządzonymi ręcznie - Smartpen, Livescribe, SkyWifi. W tym przypadku także możliwe jest przesyłanie zapisanych plików drogą elektroniczną.

Niestety, ciągle brakuje rozwiązania kompleksowego, które byłoby w stanie połączyć funkcjonalność wyżej wymienionych, a przede wszystkim dokonać konwersji mowy do tekstu za pomocą rozpoznawania mowy, przedstawić skonwertowany tekst w skompresowanej formie z zaznaczeniem terminologii, liczb, wyrażeń spójnikowych i innych wybranych przez użytkownika, połączyć elementy automatycznie wykonanych notatek z zasobami online (glosariusze, słowniki, słowosieci, konwertery jednostek miary itd.).

Fantinuoli dokonał podziału CAI na narzędzia pierwszej i drugiej generacji. CAI pierwszej generacji pojawiły się $\mathrm{w}$ pierwszej połowie lat dziewięćdziesiątych ubiegłego wieku i stanowiły głównie proste narzędzia terminologiczne, wspierające tłumacza jedynie w zakresie terminologii specjalistycznej poprzez zarządzanie glosariuszami oraz umożliwienie szybkiego wyszukania oraz wyświetlenia odpowiednich terminów. Przykładami takich programów są: Interplex ${ }^{1}$, Terminus, Interpreter's help, i DolTerm, który z czasem przekształcił się w LookUp Terminology Management ${ }^{2}$. Większość z nich nie jest już dostępna. Ich zastosowanie miało

\footnotetext{
${ }^{1}$ Por.: http://www.fourwillows.com/interplex.html. Data ostatniego dostępu: 18.08.2020.

2 Por.: http://www.lookup-web.de/features/index.html. Data ostatniego dostępu: 16.08.2020.
} 
miejsce zarówno w fazie przygotowawczej jako sposób na uporządkowanie terminologii oraz powiązanie jej ze sobą w odpowiedni sposób, jak i w fazie wykonawczej, poprzez wspieranie pamięci tłumacza. Największym problemem narzędzi pierwszej generacji była konieczność ręcznego wprowadzania danych terminologicznych, co kreowało dodatkowe obciążenie dla tłumacza.

CAI drugiej generacji to głównie InterpretBank i Intragloss. Są one o wiele bardziej zatomatyzowane w porównaniu do swoich poprzedników. Twórcy uważają, że ich narzędzia są w stanie tłumaczyć terminologię, konsultować się z materiałami online, tworzyć gotowe glosariusze na potrzeby konkretnego tłumaczenia oraz pomagać tłumaczowi w uczeniu się potrzebnych terminów na pamięć. Dodatkowo, programy te, według autorów potrafią dokonywać automatycznej ekstrakcji terminologii z materiałów przedkonferencyjnych oraz wyszukiwać jej tłumaczeń w glosariuszach, bazach danych, słownikach i innych źródłach dostępnych on-line. Narzędzia te stworzone zostały przez aktywnych thumaczy i są ciągle wzbogacane o nowe funkcje.

W literaturze przedmiotu znaleźć można także wzmiankę o narzędziach CAI trzeciej generacji, które różnią się od swoich poprzedników drugiej generacji wykorzystaniem danych w chmurze oraz systemów rozpoznawania mowy. Przykładami takich narzędzi są Flashterm ${ }^{3}$ i Interpreter's Help ${ }^{4}$.

Flashterm posiada szybką wyszukiwarkę, możliwość dodawania dodatkowych informacji do artykułu hasłowego, takich jak synonimy, odmianę, skróty, ilustracje, kontekst i inne. Wszystkie artykuły hasłowe mogą być porządkowane w grupy tematyczne. Wyszukiwarka wyszukuje artykuły hasłowe na podstawie ich nazw oraz na podstawie grup tematycznych, do których zostały przypisane. Istnieje możliwość przypisania konkretnych tłumaczeń terminów do klientów, dla których wykonywane jest tłumaczenie. Można także stworzyć listę terminologii z tłumaczeniami, których najlepiej unikać. Możliwe jest tworzenie list terminologii kluczowej, do której dostęp będzie łatwiejszy. Listy można drukować oraz udostępniać innym użytkownikom. Co więcej, można omawiać te listy na czacie. Istnieje opcja tworzenia hiperlinków do źródeł zewnętrznych, które będą pokazywały ilustracje, kontekst, przykłady zastosowań z korpusu językowego czy linki do Wikipedii. Aby zapobiec zaśmiecaniu pamięci roboczej narzędzie posiada system łączący powtarzające się artykuły

\footnotetext{
${ }^{3}$ Por.: https://www.flashterm.eu/en/. Data ostatniego dostępu: 19.08.2020.

${ }^{4}$ Por.: https://interpretershelp.com/how it works. Data ostatniego dostępu: 18.08.2020.
} 
hasłowe. Dane terminologiczne mogą być eksportowane w formatach TBX lub XML. Dostęp możliwy jest z komputerów i urządzeń mobilnych.

Interpreter's Help to narzędzie stworzone do zarządzania terminologią poprzez tworzenie glosariuszy lub importowanie już istniejących. Program obsługuje pliki MS Word i Excel. Pliki można umieścić $\mathrm{w}$ chmurze i korzystać z nich na dowolnym urządzeniu mobilnym z dostępem do Internetu oraz udostępniać innym tłumaczom. Narzędzie posiada szybką wyszukiwarkę, która pozwala na przeglądanie glosariusza w trakcie tłumaczenia. Możliwe też jest skorzystanie z Boothmate, czyli aplikacji, która pobiera glosariusz i umożliwia jego przeglądanie w momencie, gdy nie ma połączenia z Internetem. Istnieje także możliwość zapisywania historii współpracy w poszczególnymi klientami oraz przypisywania im materiałów źródłowych i glosariuszy. Można także pobierać, poprawiać i rozbudowywać glosariusze innych użytkowników, którzy udostępnili je wcześniej. Uzyskanie licencji dla tłumacza zawodowego wiąże się z opłatą, natomiast licencja dla studentów jest darmowa.

O ile powyższe możliwości są dość imponujące i zdecydowanie mogą pozytywnie wpłynąć na jakość pracy tłumacza, to dotyczą one głównie zarządzania terminologią.

Poziom znajomości technologii wspomagającej thumaczenie ustne wzrósł znacznie od marca 2020 w związku z ograniczeniami wynikającymi z epidemii COVID19. Wystarczy przejrzeć branżowe fora tłumaczy, żeby przekonać się o problemach wynikających z zaistniałej sytuacji. Wpisy świadczą także o tym, że wielu tłumaczy przed wystąpieniem ograniczeń traktowało technologię dość pobłażliwie, będący przyzwyczajonymi do „tradycyjnego” tłumaczenia. Obecnie wykorzystanie technologii wspomagającej tłumaczy ustnych polega głównie na używaniu komputerów i urządzeń mobilnych, za pomocą których można przeglądać materiały źródłowe, zarządzać terminologią, tworzyć glosariusze przeznaczone na potrzebny konkretnych tłumaczeń, sprawdzać terminologię specjalistyczną a także inne zagadnienia natury językowej. Jak już wspomniano, brakuje rozwiązania kompleksowego, łączącego możliwości kilku narzędzi.

\section{Pamięci thumaczeniowe a thumaczenia ustne}

Tworzenie i wykorzystanie pamięci tłumaczeniowych (TM) w przypadku tłumaczeń konsekutywnych wydaje się być problematyczne. Presja czasu ogranicza możliwość ich zastosowania. Wygłaszany tekst musiałby być zarejestrowany przez mikrofon, przekonwertowany do postaci tekstu, porównany z TM i w przypadku znalezienia podobieństw wyświetlony tłumaczowi. Nawet gdyby proces ten trwał kilka milisekund, to tłumacz mógłby 
skorzystać z wyników dopiero po analizie pierwszego segmentu. Dodatkowo, pozostaje ograniczenie w postaci prędkości czytania i analizowania przez tłumacza. Stosowanie takiej technologii mogłoby wydłużyć opóźnienie pomiędzy nadawcą inicjalnym a nadawcą wtórnym. Co więcej, jeżeli skala podobieństwa spadłaby do 80 lub 70\%, to opóźnienie to wydłużyłoby się jeszcze bardziej.

Tworzenie pamięci tłumaczeniowych $\mathrm{z}$ tłumaczeń konsekutywnych wymagałoby nagrywania tłumaczenia segmentów i łączenia go z tekstem wyjściowym. Największym ograniczeniem jest konieczność stworzenia precyzyjnego i szybkiego oprogramowania do rozpoznawania mowy i przetwarzania jej do postaci tekstu. Oprogramowanie takie musiałoby być $\mathrm{w}$ stanie radzić sobie $\mathrm{z}$ różnymi akcentami, błędami $\mathrm{w}$ wymowie, technikami $\mathrm{i}$ prędkościami wypowiedzi i innymi.

\section{Rozpoznawanie mowy}

Kluczowym elementem narzędzi CAI są narzędzia do rozpoznawania mowy (ASR), które:

- Posiadają możliwość rozpoznawania mowy spontanicznej, improwizowanej, o różnorodnej prędkości i zmiennej głośności. W analizowanej mowie występować będą braki odstępów między wyrazami, wtrącenia i dygresje odbiegające od ogólnej tematyki wypowiedzi, przerwy, urwane wyrazy, powtórzenia, dźwięki sugerujące zastanawianie się, błędy i problemy z wymową. Dodatkowo, analizowana mowa warunkowana będzie przez takie czynniki jak płeć, wiek, dialekt, akcent, emocje, styl, zmiany osoby mówiącej. Problematyczne są także niejednoznaczności wynikające z homonimii i homofonii.

- Cechują się szybkim czasem reakcji i zwrotu wyników pracy oraz wysokim stopniem precyzji oferowanych wyników. W przypadku MagicScribeMedical ${ }^{5}$ prędkość $^{-}$ interpretacji wynosi 160 słów na minutę przy dokładności na poziomie 98\%. Narzędzie Techmo Dictation ${ }^{6}$ badano na materiale różnych tekstów. Dokładność wyników wynosi od 93\% w przypadku tekstów z dziedziny bankowości, do 96,35\% w przypadku tekstów prawniczych.

- Posiada możliwość radzenia sobie z zakłóceniami, np. dźwięki z otoczenia.

\footnotetext{
${ }^{5}$ Por.: https://magicscribesklep.pl/pl/p/Magic-Speech-Scribe-Administracja-Subskrypcja-90-ciodniowa/88. Data ostatniego dostępu: 21.08.2020.

${ }^{6}$ Por.: https://demo.devtechmo.pl/new/dictation.html. Data ostatniego dostępu: 20.08.2020.
} 
- Posiada formę bezobsługową - thumacz nie może poświęcać uwagi procesowi rozpoznawania mowy i jej konwersji do postaci tekstu.

- Posiada możliwość wykorzystania podpiętych słowników, co pozwala na zachowanie ścisłości terminologicznej oraz poprawności gramatycznej i stylistycznej, możliwość rozbudowywania słowników, dodawania nowych artykułów hasłowych i edycji już istniejących

- W dalszej perspektywie, system będzie w stanie automatyczne tworzyć cyfrowe banki wypowiedzi w formie połączenia dźwięku i transkrypcji, z możliwością połączenia tłumaczeń tychże segmentów.

Do najpopularniejszych rozwiązań ASR należą Dragon Naturally Speaking ${ }^{7}$, MagicScribeMedical $^{8}$, Interpretbank $\mathrm{ASR}^{9}$, i produkty firmy Techmo ARS, Dictation i Pathfinder ${ }^{10}$.

\section{Narzędzie kompresujące}

Kolejnym elementem kompleksowego narzędzia CAI jest oprogramowanie pozwalające na automatyczną kompresję tekstu otrzymanego dzięki narzędziom ASR. Kompresja tekstowa jest zabiegiem stosowanym m.in. w procesie thumaczenia, ukierunkowanym na eliminację nadmiaru środków językowych, czyli redukcję postaci materialnej jednostek użytych do wyrażenia określonego quantum informacji. W wyniku zastosowania kompresji możliwe jest uzyskanie optymalnej dla zakładanego odbiorcy struktury tekstu, która pozwoli mu na jak najpełniejsze zrekonstruowanie znaczenia zamierzonego przez nadawcę (Sitkowski 2016: 9$60)$.

W przypadku tłumaczeń konsekutywnych, stosowanie kompresji tekstowej na tekście pozwoli na wyodrębnienie najważniejszych informacji oraz przedstawienie ich za pomocą form, które są zwięzłe a jednocześnie maksymalnie informacyjne. Właściwy dobór algorytmu kompresji pozwoli uniknąć strat w wartości informacyjnej komunikatu.

Wyróżnić należy następujące rodzaje kompresji tekstowej:

\footnotetext{
${ }^{7}$ Por.: https://www.nuance.com/dragon/business-solutions/dragon-professional-anywhere.html. Data ostatniego dostępu: 20.08.2020.

${ }^{8}$ Por.: https://magicscribesklep.pl/pl/p/Magic-Speech-Scribe-Administracja-Subskrypcja-90-ciodniowa/88. Data ostatniego dostępu: 21.08.2020.

${ }^{9}$ Por.: http://interpretbank.com/ASR. Data ostatniego dostępu: 18.08.2020.

10 Por.: https://www.facebook.com/TechmoVoice. Data ostatniego dostępu: 24.08.2020.
} 
a) terminologiczna, czyli zapisywanie terminów w jak najzwięźlejszej postaci, np. za pomocą skrótowca lub poprzez ucięcie,

b) semantyczną, polegającą na redukcji jednego lub wielu elementów terminu wielowyrazowego bez zmniejszenia wartości informacyjnej. Możliwe jest to dzięki istnieniu elementu, który pozwala na odtworzenie znaczenia elementu usuniętego,

c) semiotyczną, czyli stosowanie kodów semiotycznych. Rozwiązanie takie jest niezmiernie popularne w notatkach tłumaczy konsekutywnych, ponieważ pozwala na reprezentację wiedzy za pomocą niejęzykowej reprezentacji znakowej,

d) kognitywną, a więc pomijanie wszelkich elementów, które ze względu na kontekst są łatwe do zapamiętania i rekonstrukcji wyrażonych za ich pomocą informacji. Elementami takimi mogą być wielokrotnie powtarzające się koncepty.

Narzędzie dokonujące kompresji wymaga zastosowania słowników, które będą określały jaką kompresję zastosować. W słownikach, poza terminami powinny też znajdować się odpowiadające im skróty, które pojawiać się będą w proponowanych notatkach. Poza terminologią, tłumacz stworzyć może własną bazę wyrażeń popularnych, np. wyrażeń spójnikowych, do których dodany zostanie symbol (zastosowanie kompresji semiotycznej). Przypisany symbol będzie widoczny $\mathrm{w}$ proponowanych notatkach po przeprowadzeniu kompresji. Liczebniki dla dużych liczb nie będą zapisywane cyframi, tylko za pomocą skrótu, np. tys., mil, mld, bln.

Zbudowanie narzędzia kompresującego jest kolejnym kluczowym wyzwaniem na drodze do zrewolucjonizowania zawodu tłumacza konsekutywnego.

\section{Problemy rozwojowe}

Narzędzia CAI nie są bardzo popularne, a obecne rozwiązania dotyczą głównie zabezpieczenia poprawności i precyzji terminologicznej tłumaczonych tekstów. Za przyczynę takiego stanu rzeczy uznać można:

- Temat CAI jest ciągle mało rozwinięty i opisany w literaturze przedmiotu. L. Wagener (2012) przeprowadziła badanie, w którym udział wzięło 102 zawodowych tłumaczy konferencyjnych. Z wyników wynika, że zaledwie 15\% tłumaczy korzysta z narzędzi terminologicznych, a 26\% tłumaczy używa specjalistycznego oprogramowania. Większość badanych ciągle preferuje używanie papierowych materiałów. Tylko 20\% uczestników zadeklarowało pracę bez wykorzystania źródeł papierowych 
- Przekonanie o tym, że skoro udaje się wykonywać tłumaczenia ustne bez CAI, to nie ma sensu inwestować czasu, wysiłku i środków finansowych

- Koszt narzędzi CAI

- Konieczność szkolenia z obsługi narzędzi CAI

- Narzędzia CAI są tematem mało popularnym i rzadko poruszanym w trakcie zajęć praktycznych z tłumaczeń ustnych.

Skuteczność narzędzi terminologicznych poddana została badaniu przeprowadzonym przez Gacek (2015). Z otrzymanych danych wynika, że zastosowanie odpowiedniego oprogramowania $\mathrm{w}$ trakcie tłumaczenia daje lepsze efekty niż stosowanie tradycyjnych glosariuszy papierowych. W innym badaniu, opisanym przez Biagini (2016), tekst będący obiektem eksperymentu charakteryzował się wysokim stopniem nasycenia terminologicznego. Porównywano dwie sytuacje tłumaczeniowe. W jednej z nich stosowano oprogramowanie CAI, w drugiej natomiast papierowe glosariusze. Badanie dowiodło, że wykorzystanie narzędzi CAI pozytywnie przekłada się na ścisłość terminologiczną oraz mniejszy poziom strat informacyjnych tłumaczonego tekstu. Ta informacja jest kluczowym argumentem przemawiającym za koniecznością rozwoju i popularyzacji kompleksowych narzędzi CAI. Skoro wsparcie thumacza nawet pod kątem terminologii przynosi pozytywne efekty, to rozbudowanie funkcjonalności narzędzi CAI może zrewolucjonizować zawód tłumacza ustnego.

\section{Kompresje w thumaczeniu konsekutywnym}

$\mathrm{Na}$ początku niniejszego podrozdziału należy przyjąć, że oprogramowanie CAI pozwala osiągnąć wyższy stopień poprawności tłumaczenia (terminów), wyższy współczynnik ścisłości terminologicznej i niższy współczynnik terminów pominiętych w thumaczeniu, co oznacza dokładniejsze i poprawniejsze tłumaczenia. Najważniejszym zadaniem narzędzi CAI jest odciążenie tłumacza poprzez wspieranie jego pamięci, prezentowanie skompresowanej informacji w czytelny i logiczny sposób, tak aby na jej podstawie możliwe było odtworzenie sensu komunikatu wyjściowego.

Wiele elementów językowych, takich jak m.in. wartości liczbowe, skróty i skrótowce wg. Gile'a (2009: 194) stanowią zagadnienia problematyczne, które w znacznym stopniu obciążają zasoby umysłowe tłumacza, prowadząc do przeciążenia kognitywnego i w następstwie mogą przyczyniać się do powstawania błędów czy nieścisłości. Jakikolwiek stopień odciążenia tłumacza przekłada się na podniesienie jakości tłumaczenia. 
Zadaniem aplikacji jest przetworzenie informacji napływających tak, aby osiągnąć optymalny poziom skompresowania jednostek informacyjnych. Jednostka taka jest najmniejszą możliwą postacią zapisu danej informacji, która w danym kontekście pozwala na zrekonstruowanie właściwego znaczenia. Optymalny poziom skompresowania jednostek informacyjnych uzależniony jest od kontekstu sceny tłumaczeniowej, na który składają się trzy czynniki:

- kontekst tłumacza - jego wiedza, warsztat, możliwości zapamiętywania,

- kontekst informacji - nasycenie terminologiczno-informacyjne tekstu,

- kontekst odbiorców - ich poziom wiedzy specjalistycznej i językowej określający, który poziom kompresji lub ekspansji można zastosować, tak aby na podstawie otrzymanego tłumaczenia odbiorcy mogli zrekonstruować wyrażone znaczenie.

Poniższy schemat obrazuje zależności warunkujące osiągnięcie optymalnego poziomu skompresowania struktury jednostki informacyjnej.

Schemat 1. Zależności warunkujące osiągnięcie optymalnego poziomu skompresowania struktury jednostki informacyjnej.

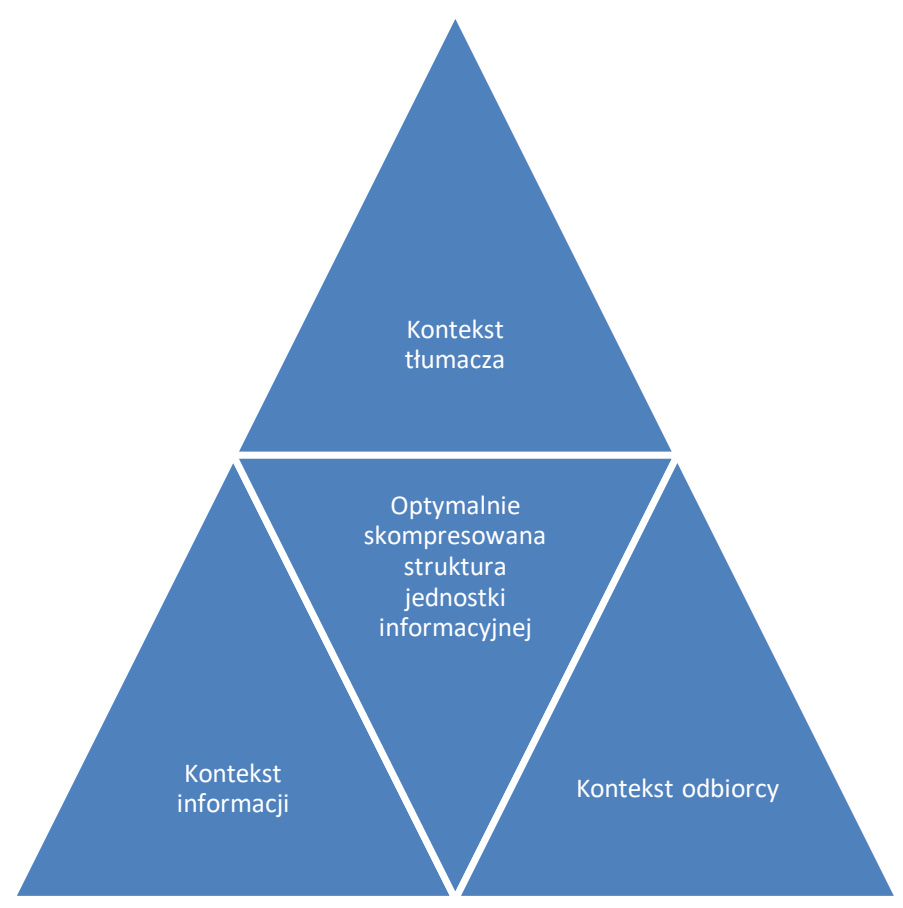

\section{Faza przygotowawcza thumaczenia}

Narzędzie CAI może być wykorzystywane zarówno jako pomoc w trakcie przygotowań do tłumaczenia, jaki i w trakcie samego zadania tłumaczeniowego. Faza przygotowawcza polega 
na wprowadzeniu do narzędzia wszelkich materiałów źródłowych, takich jak listy terminologii, glosariusze, słowosieci, teksty dotyczące tłumaczonej tematyki, linki do słowników i encyklopedii językowych i przedmiotowych. Następnie tłumacz, wykorzystując glosariusze opracowuje listę najpopularniejszych, wg. niego terminów i związków frazeologicznych, które mogą pojawić się w tłumaczonym tekście. Dotyczyć to może dopasowania czasownika do rzeczownika, np. produkt - proces, wartości liczbowe lub daty powiązane z terminami (wydarzenie - data) itp. Do najpopularniejszych wyrażeń, tj. wyrażeń spójnikowych dodawane są symbole, które będą stosowane zamiast pełnych form w trakcie kompresji.

Faza przygotowawcza to także próby zgłębienia danego zagadnienia oraz zapamiętania jak największej ilości terminologii, dlatego też narzędzie powinno też zawierać komponent wspomagający naukę terminologii.

\section{Kompleksowe narzędzie CAI}

$\mathrm{Na}$ podstawie powyższych rozważań stwierdzić można, że kompleksowe narzędzie CAI powinno składać się z takich komponentów jak:

- system automatycznego rozpoznawania mowy (Dragon Naturally Speaking, MagicScribe, Interpretbank ASR, Techmo ASR, Dictation i Pathfinder),

- aplikacja zarządzająca terminologią (InterpretBank, Intragloss, Flashterm, Interpreter's Help),

- aplikacja dokonująca kompresji tekstu oraz wyświetlająca jej wyniki w czasie rzeczywistym,

- ekran dotykowy z możliwością stosowania rysika za pomocą którego wprowadzane będą uzupełnienia notatek automatycznych.

Scenariusz współpracy z narzędziem CAI wygląda następująco:

1. Nadawca inicjalny wygłasza przemowę

2. ASR tworzy zapis wypowiedzi w czasie rzeczywistym, a tłumacz zaznacza najważniejsze informacje, które $\mathrm{w}$ kolejnym korku są prezentowane $\mathrm{z}$ skompresowanej postaci. Na lewym marginesie najważniejsze terminy. Konieczność wprowadzania informacji do narzędzia CAI wiąże się z możliwymi rozproszeniami uwagi, ponieważ w grę wchodzą dwie czynności - słuchanie i pisanie. Dlatego też zastosowanie oprogramowania ASR jest konieczne.

3. Tekst poddany jest analizie. Oznaczane są terminy i ich związki frazeologiczne, stosowana jest kompresja, oznaczane są wyrażenia łączące i organizujące wypowiedź, 
oznaczane są nazwy własne, skróty, skrótowce i wartości liczbowe, przeprowadzona jest konwersja jednostek miary. Narzędzie do zarządzania terminologią przeprowadza analizę i przedstawia jej wyniki.

4. Skompresowane postaci informacji są wyświetlane na ekranie tłumacza, na którym może on wprowadzać zmiany, zaznaczać najważniejsze informacje, które będą przedstawione w sposób odróżniający się on innych, eliminować niepotrzebne informacje, dodawać połączenia elementów oraz dodawać informacje. Tłumacz może także skorzystać z podpiętych słowników i innych źródeł do, np. przestawienia ilustracji, rozwinięcia terminu, czy prezentacji alternatywnych ekwiwalentów terminów. Aplikacja łączy się z glosariuszami, słownikami i innymi materiałami źródłowymi w celu przedstawienia ekwiwalentów terminologii oraz ewentualnych definicji. Definicje pojawiają się dopiero po wybraniu danego terminu. Każdy z terminów może być prezentowany jako centralne pojęcie słowosieci, tak aby wyświetlić wyrażenia, z którymi się kolokuje.

5. CAI współpracuje $\mathrm{z}$ bankiem terminologii zgromadzonej w fazie przygotowawczej. Za każdym razem, gdy program rozpozna termin $\mathrm{z}$ bazy, przedstawi go w skompresowanej formie. Forma ta może być wprowadzona manualnie - symbol przypisany do terminu przez tłumacza lub automatycznie, np. ucięcie lub zapis bez samogłosek.

6. Tłumacz korzystając $\mathrm{z}$ wykonanych notatek może rozpocząć tłumaczenie konsekutywne.

Do opisanych powyżej rozwiązań dodać można kolejne elementy. Jednym z nich jest opisana przez Wolińskiego (2019) próba przeprowadzenia automatycznej analizy składniowej, dzięki której tekst podzielony zostanie na zdania, a następnie zdania zostaną rozbite na części pierwsze (części mowy wraz z informacją o ich formie). Na tej podstawie tekst zostanie przedstawiony w postaci zbioru drzew składniowych, które z kolei zostaną skompresowane.

\section{Wnioski}

Ze względu na małe zainteresowanie kompleksowymi narzędziami CAI, wyżej opisane rozwiązania są jedynie propozycją jednego z wielu możliwych scenariuszy rozwoju. Niemniej jednak warto poświęcić więcej uwagi narzędziom CAI, ponieważ, jak już wspomniano, ich rozwój zdecydowanie doprowadzi do zrewolucjonizowania tłumaczeń ustnych. 
Na podstawie istniejących rozwiązań informatycznych zbudować można kompleksowe narzędzie CAI, które wspierać będzie tłumaczy ustnych. Największym problemem wydaje się być sprawdzenie możliwości integracji istniejących aplikacji, połączenie poszczególnych narzędzi w jedno lub stworzenie jednej aplikacji posiadającej funkcjonalność odpowiadającą wyżej wymienionym. Dodatkowo, konieczne jest opracowanie algorytmów związanych z przetwarzaniem języka, gramatykami, wyszukiwaniem informacji, sieciami neuronowymi oraz zaprojektowanie narzędzia dokonującego kompresji tekstu. Istnieją już rozwiązania polegające na automatycznym streszczaniu tekstu, jednakże osiągane przez nie wyniki są dalekie od zadowalających. Temat ten stanowić będzie kontynuację badań opisanych w niniejszym artykule.

\section{Bibliografia}

Biagini, Giulio (2016) Printed Glossary and Electronic Glossary in Simultaneous Interpretation: A Comparative Study. [pobrane $\mathrm{z}$ https://www.academia.edu/23759751/Glossario_cartaceo_e_glossario_elettronico_durante _linterpretazione_simultanea_uno_studio_comparativo. Data ostatniego dostępu: 28.08.2020].

Compas Pastor, Gloria (2017) „VIP: Voice-Text Integrated Systems for Interpreters”. [W:] João Esteves-Ferreira, Juliet Macan, Ruslan Mitkov, Olaf-Michael Stefanov (red.) Proceedings of the 39th Conference Translating and Computer. London: Tradulex; 7-10.

Fantinuoli, Claudio (2016) „InterpretBank. Redefining Computer-Assisted Interpreting Tools”. [W:] João Esteves-Ferreira, Juliet Macan, Ruslan Mitkov, Olaf-Michael Stefanov (red.) Proceedings of the Translating and the Computer 38 Conference. London: Tradulex; 42 52.

Fantinuoli, Claudio (2018) „Computer-Assisted Interpreting: Challenges and Future Perspectives". [W:] Gloria Corpas Pastor, I. Durán Muñoz (red.) Trends in e-tools and Resources for Translators and Interpreters. Leiden: Brill; 153-174.

Gacek, Michael (2015) Softwarelosungen fur DolmetscherInnen. Vienna: Uniwien. [pobrane z http://othes.univie.ac.at/35667/1/2015-01-16_0607925.pdf. Data ostatniego dostępu: 01.09.2020].

Gile, Daniel (2009) Basic Concepts and Models for Interpreter and Translator Training. Revised Edition. Amsterdam/Philadelphia: John Benjamins. 
Pochhacker, Franz (red.) (2015) Routledge Encyclopedia of Interpreting Studies. London/New York: Routledge.

Prandi, Bianca (2017) „Designing a Multimethod Study on the Use of CAI Tools during Simultaneous Interpreting”. [W:] João Esteves-Ferreira, Juliet Macan, Ruslan Mitkov, Olaf-Michael Stefanov (red.) Proceedings of the 39th Conference Translating and Computer. London: Tradulex; 76-88.

Rutten, Anja (2017) „Terminology Management Tools for Conference Interpreters - Current Tools and How They Address the Specific Needs of Interpreters". [W:] João EstevesFerreira, Juliet Macan, Ruslan Mitkov, Olaf-Michael Stefanov (red.) Proceedings of the 39th Conference Translating and Computer. London: Tradulex; 98-103.

Seleskovitch, Danica (1975) „Language and Memory: A Study in Note-taking in Consecutive Interpreting”. [W:] Franz Pochhacker, Miriam Shlesinger (red.) The Interpreting Studies Reader. London, New York: Routledge; 120-129.

Sitkowski, Krzysztof (2016) Rola i znaczenie kompresji tekstowej w przekładzie pisemnym (na materiale tekstów technicznych). Niepublikowana rozprawa doktorska.

Wagener, Leonie (2012) „Vorbereitende Terminologiearbeit im Konferenzdolmetschen unter besonderer Berücksichtigung der Zusammenarbeit im Dolmetschteam”. Master thesis, University of Applied Sciences Cologne, Faculty of Information and Communication Sciences, Institute for Translation and Multilingual Communication.

Woliński, Marcin (2019) Automatyczna analiza składniowa języka polskiego. Warszawa: Wydawnictwa Uniwersytetu Warszawskiego.

\section{Strony internetowe}

http://interpretbank.com/. Data ostatniego dostępu: 18.08.2020.

http://interpretbank.com/ASR. Data ostatniego dostępu: 18.08.2020.

http://www.fourwillows.com/interplex.html. Data ostatniego dostępu: 18.08.2020. http://www.lookup-web.de/features/index.html. Data ostatniego dostępu: 16.08.2020. https://demo.devtechmo.pl/new/dictation.html. Data ostatniego dostępu: 20.08.2020. https://interpretershelp.com/how_it_works. Data ostatniego dostępu: 18.08.2020. https://magicscribemedical.pl/._Data ostatniego dostępu: 21.08.2020. https://www.facebook.com/TechmoVoice. Data ostatniego dostępu: 24.08.2020. https://www.flashterm.eu/en/. Data ostatniego dostępu: 19.08.2020. 
https://www.nuance.com/dragon/business-solutions/dragon-professional-anywhere.html/. Data ostatniego dostępu: 20.08.2020. 